\title{
Al-Qarinah: antara Kekuatan dan Keperluan dalam Mensabitkan Kesalahan Jenayah (Zina)
}

\author{
Al-Qarinah: between the Strength and Requirements to Convict Crime (Adultery)
}

LUKMAN ABDUL MUTALIB* \& WAN ABDUL FATTAH WAN ISMAIL ${ }^{1}$

\begin{abstract}
Justice is the ultimate objective of any judiciary system. The absolute justice is only belongs to Islamic judiciary system. However it is highly dependent on the quality of the implementation methodology that man could produce. In the Islamic judiciary system, especially to convict a zina, there are various methods in establishing evidence. Some of the methods are unanimously accepted while some others are not unanimously accepted. Al-qarinah is among those which are not unanimously accepted by the Islamic jurists. The Islamic law is actually dynamic. The dynamism lies on its flexibility, which is the main characteristic of the law itself. It is because the fiqh law is not isolated from reality, but derived from the analysis on the contemporary environments. The development in science and technology has changed the human civilisation and perception towards life. The development of knowledge in producing evidence scientifically such as DNA test, fingerprint etc. coupled with the more complex criminal behaviour, demand us to take a detailed and in-depth study to determine the status of al-qarinah in the contemporary Islamic judiciary system in order to make sure an Islamic law is relevant and effort to give a justice and positive perception among nation toward Islam.
\end{abstract}

Keywords: Islamic law, hudud, evidence, maslahat, al-qarinah.

Seorang hakim memerlukan tiga perkara. Tanpa tiga perkara ini sesuatu penghakiman tidak akan sempurna iaitu mengetahui dalil, sebab dan keterangan. Mengetahui dalil bermaksud mengetahui nas syar'ie. Mengetahui sebab pula ialah tahu bagaimana perkaitan antara dalil dan masalah atau kes. Manakala keterangan pula ialah kaedah atau cara untuk menzahirkan keadilan dalam proses perbicaraan. Apabila wujud kesilapan dalam salah satu dari tiga perkara tersebut maka berlakulah kesilapan dalam penghakiman. Banyak kesilapan hakim adalah berpunca dari tiga perkara tersebut atau salah satu daripadanya (Ibn al-Qayyim alJawzi 1996). Al-Qarinah dan pemakaiannya di dalam undang-undang keterangan Islam adalah skop yang menarik untuk dikaji. Ini kerana perubahan masa dan perkembangan ilmu pengetahuan telah mengubah kedudukannya dari bukti keterangan yang tidak begitu penting pada suatu masa dahulu telah menjadi sangat penting pada hari ini. Al-Qarinah dari sudut bahasa bererti melazimi atau sentiasa bersama (al-Syawkany: t.th.). Firman Allah:

\footnotetext{
${ }^{1}$ Lukman Abdul Mutalib*(Corresponding author). Ph.D. and Wan Abdul Fattah Wan Ismail, Ph.D. Lecturer at Faculty of Syariah and Laws, Universiti Sains Islam Malaysia, 71809 Bandar Baru Nilai, Negeri Sembilan Darul Khusus. Email: lukman912@gmail.com.
}

https://doi.org/10.24035/ijit.2.2012.004 


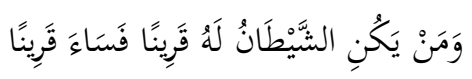

Maksud:

Sesiapa yang menjadikan syaitan itu sebagai rakan baik yang sentiasa bersama dengannya, maka itulah seburuk-buruk rakan (al-Quran al-Nisaa', $4: 38)$.

Dari sudut istilah pula, para fuqaha' silam mendefinisikannya sebagai amarah atau tanda. Mereka tidak mendefinisikannya secara jitu (takrif yang jami' dan mani') mungkin kerana ia adalah perkataan yang sedia difahami dengan mudah, justeru tidak perlu kepada takrif yang lengkap. Namun setelah ilmu ini berkembang dan semakin penting untuk diketahui oleh orang ramai maka wujudlah satu takrif yang jami' dan mani'. Oleh itu qarinah mengikut definisinya yang jitu ialah suatu nyataan yang zahir ada hubungan dengan nyataan yang tersembunyi. Melalui hubungan tersebut, ia membawa kepada suatu maksud tertentu yang menjadi fakta kes ('Adnan Hasan 'Azayizah 1990). Sebagai contoh dalam kes peminangan anak dara, sebagaimana yang ditegaskan oleh Nabi s.a.w tanda persetujuannya ialah diam (tidak membantah). Diam adalah nyataan zahir, namun bukan itu yang dikehendaki dalam kes ini. Apa yang dikendaki ialah diam bermaksud tidak membantah, tidak membantah bermaksud setuju (nyataan yang tersembunyi). Justeru, diam adalah qarinah tanda setuju.

Qarinah mempunyai berbagai jenis dilihat dari aspek yang berbeza. Iaitu aspek sumber terdiri dari qarinah qanuniyyah dan qada'iyyah, dari aspek fizikal qarinah haliah dan maqaliah, dari aspek hubungkait dengan fakta kes qarinah 'aqliyyah dan 'urfiyyah ('Adnan Hasan 'Azayizah 1990). Setiap al-qarinah mempunyai darjah kekuatannya masingmasing, kerana itu tidak semuanya diterima sebagai dalil keterangan. Sebaliknya hanya yang bersifat qatiyyah (kuat) sahaja yang boleh dijadikan hujah. Lazimnya, al-qarinah merupakan himpunan kaitan-kaitan peristiwa yang boleh menarik kepada satu kesimpulan. Berasaskan kepada kaitan-kaitan peristiwa yang banyak ini ia membentuk satu kesimpulan yang kukuh dan boleh mencapai ke tahap yakin. ${ }^{2}$ Ia boleh diibaratkan sebagai seutas tali untuk menggantung sesuatu objek. Dengan hanya seutas tali tindakan ini mungkin tidak memadai, tetapi dengan lima utas tali yang bergabung ia akan menjadi lebih kuat dan begitulah seterusnya.

2 Dengan bersandarkan kepada hanya satu al-qarīnah sahaja tidak memadai untuk menyabitkan sesuatu kesalahan. Lazimnya dalam perbahasan ulama fikah mengenai al-qarīnah, ia sama-sekali tidak menggambarkan konsep ini secara jelas. Mereka mengkaji al-qarinah dari sudut yang terpisah antara satu al-qarinah dengan al-qarīnah yang lain, walaupun dalam kes yang sama. Contohnya sabitan terhadap tuduhan meminum arak, ia dibuktikan melalui al-qarinah bau atau alqarinah muntah. Dalam kes zina ia dibuktikan melalui mengandung tanpa suami. Pada pandangan penulis hakikatnya tidak demikian, dalam kes zina umpamanya Sayidina 'Umar tidak mungkin hanya bersandarkan kepada al-qarinah mengandung semata-mata sebaliknya pasti ada bukti-bukti lain yang menyokong tuduhan tersebut, walau bagaimanapun mengandung adalah al-qaiinah yang paling kukuh, kerana itu ia difokuskan. Secara logiknya sebelum sesuatu hukuman itu dijatuhkan pasti ada perbicaraan (pertuduhan dan pembelaan), malangnya ia tidak dinukilkan oleh sejarah.

https://doi.org/10.24035/ijit.2.2012.004 


\section{Kepentingan Bukti dan Keterangan}

Melaksanakan proses kehakiman yang adil dan saksama adalah satu tuntutan. Terdapat banyak ayat al-Quran dan al-Hadis yang memerintahkan kita agar menegakkan keadilan. Antaranya firman Allah s.w.t:

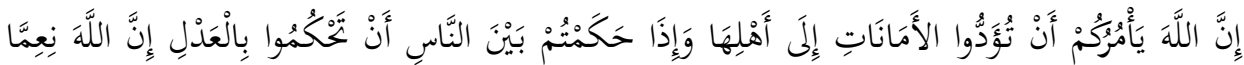

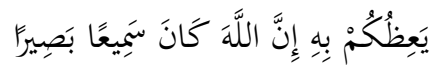

Maksud:

Sesungguhnya Allah memerintah kamu menyampaikan amanah kepada yang berhak menerimanya dan (menyuruh kamu) apabila memutuskan sesuatu pengadilan sesama manusia agar kamu memutusnya dengan adil. Sesungguhnya Allah s.w.t memberi sebaik-baik pengajaran kepadamu. Sesungguhnya Allah s.w.t Maha Mendengar lagi Maha Melihat (al-Quran, alNisa' 4: 58).

Menurut Imam al-Qurtuby, ayat di atas merupakan prinsip asas syariat Islam, iaitu manusia diseru agar bersifat amanah dan berlaku adil. Kedua-dua sifat ini adalah tunjang kepada keharmonian hidup manusia di dunia malah ia menjadi sebab utama untuk manusia menikmati kesejahteraan hidup di akhirat (al-Qurtuby 1964). Dalam menegakkan keadilan dan kesaksamaan ini, ia memerlukan kepada beberapa perkara, antaranya ialah keperluan terhadap satu sistem undang-undang yang adil dan saksama, kaedah perlaksanaan yang cekap dan sempurna serta bukti keterangan yang tepat dan benar. Dalam mencari kebenaran, keterangan adalah sangat penting khususnya dalam setiap prosiding kehakiman. Kelancaran dan keberkesanan sesuatu perbicaraan tertakluk sejauh mana bukti dan keterangan yang berjaya diperoleh oleh mahkamah. Dengan keterangan, seorang hakim akan dapat membezakan antara yang benar dari yang salah, bahkan setiap hukuman yang diputuskan oleh hakim mestilah berdasarkan kepada keterangan dan bukti tersebut. Rasulullah s.a.w bersabda:

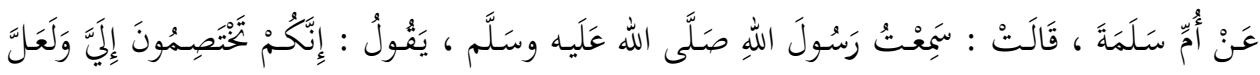

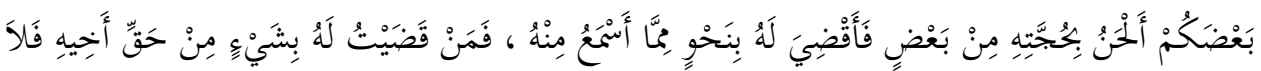

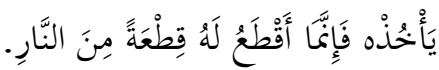

Maksudnya:

Dari Ummi Salamah. beliau berkata bahawa Rasulullah s.a.w. telah bersabda; kamu telah bertikai dihadapanku, mungkin ada di antara kamu yang lebih petah berhujah (memberi keterangan) dari yang lain, lalu aku menghukum berdasarkan dari apa yang aku dengar darinya. Sesiapa yang telah aku hukumkan (berikan) untuknya sesuatu dari hak saudaranya ( yang ia tidak 
berhak tetapi diperoleh lantaran hujahnya yang petah) janganlah ia mengambilnya kerana dengan itu aku telah memotong untuknya sekeping api neraka (al-Nawawy 1991).

Sabda Baginda lagi:

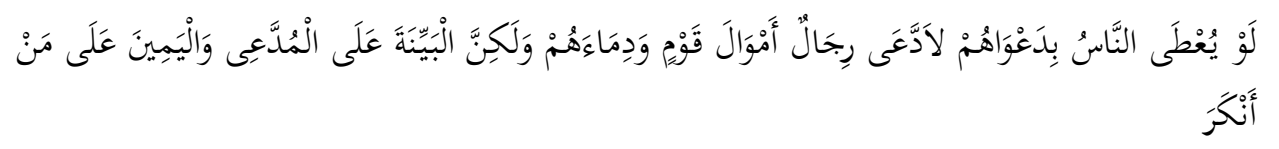

Maksudnya:

Andainya semua orang boleh diberikan hukuman semata-mata kerana adanya dakwaan, pastilah semua orang akan membuat dakwaan terhadap harta dan darah orang lain tetapi sebaliknya setiap pendakwa mestilah mendatangkan keterangan dan yang engkar mestilah bersumpah (al-Bayhaqy 1993).

Melalui ayat al-Quran dan hadis Nabi s.a.w di atas dapat kita fahami bahawa keterangan dan bukti adalah asas terpenting dalam menegakkan keadilan. Oleh itu ia perlu tepat dan jelas. Tanpa keterangan yang tepat dan benar sudah pasti keadilan tidak dapat ditegakkan. Lantaran itu, kita melihat syariat Islam memberikan satu garis panduan yang ketat dalam menilai kesahihan sesuatu keterangan yang diberi seperti memperincikan kelayakan seseorang saksi yang layak dibawa ke mahkamah dan sebagainya (Mahmud Saedon 1990).

\section{Keterangan (al-Bayyinah)}

Dalam undang-undang keterangan Islam, bukti atau keterangan ini dikenali dengan istilah al-bayyinah (Enakmen Keterangan Mahkamah Syariah 1994 negeri Perak). Dari segi penggunaan bahasa al-bayyinah bererti terang, jelas dan nyata. Oleh itu penggunaannya di dalam undang-undang keterangan Islam merujuk kepada sesuatu yang menjelaskan atau menerangkan sesuatu hak atau kepentingan. Manakala pengertiannya menurut istilah syarak pula terbahagi kepada dua pendapat (Muhammad Ra'fat 1992). Pendapat yang pertama ialah al-bayyinah bermaksud kesaksian (al-syahadah). Pendapat ini di dokong oleh kebanyakan ulama (jumhur ulama'). Pendapat yang kedua pula ialah al-bayyinah bermaksud bukti keterangan. Iaitu bukti, hujah dan dalil. Pendapat kedua ini menerima albayyinah sebagai apa sahaja bentuk keterangan yang dapat membantu, menjelaskan, menerangkan, atau membuktikan sesuatu kes yang dibicarakan dalam proses menegakkan kebenaran dan keadilan yang dituntut. Pendapat ini didokong oleh Ibn Taimiyyah dan Ibn al-Qayyim serta ulama yang sependapat dengannya. Manakala dalam Enakmen Keterangan Mahkamah Syariah di Malaysia, al-bayyinah ditafsirkan sebagai keterangan. Dalam enakmen ini kedudukan al-bayyinah telah dibezakan dengan al-syahadah secara jelas. ${ }^{3}$ Ini

3 Seksyen 3 (1) Enakmen Keterangan (Mahkamah Syariah) 1994-Perak Darul Ridwan. Enakmen Keterangan Mahkamah Syariah 1991 (Kelantan) Demikian juga Akta Keterangan 1950. Undang-Undang Malaysia 1956. 
menunjukkan, sungguhpun pendapat kedua merupakan pendapat minoriti, tetapi dalam pendekatannya menangani keadilan seiring dengan perubahan masa dan kemajuan teknologi telah membuktikan bahawa pentafsiran yang diguna pakai olehnya adalah lebih relevan dengan dunia moden hari ini. Menegakkan keadilan adalah matlamat utama sistem kehakiman. Terlalu banyak dalil yang memerintah agar berlaku adil dan mengelak dari perbuatan zalim. Bahkan konsep keadilan tidak terhad hanya kepada sesama Islam tetapi juga meliputi seluruh manusia dan haiwan. Bukti keterangan adalah salah satu elemen terpenting di dalam menegakkan keadilan. Sesuatu dakwaan yang tidak didokong oleh bukti dan hujah tidak akan memberikan apa-apa kesan dalam sistem kehakiman, bahkan segala keputusan hakim adalah tertakluk sepenuhnya kepada sejauh mana bukti yang diperoleh. Kenyataan ini berdasarkan kepada hadis Rasulullah s.a.w sendiri. Justeru, perkataan albayyinah yang membawa erti 'keterangan' hakikatnya tidak terbatas kepada pengertian shahadah semata-mata. Sebaliknya ia adalah sebarang hujah atau dalil yang dapat menzahirkan kebenaran tidak kira dalam apa jua bentuknya. Sabda Rasulullah s.a.w:

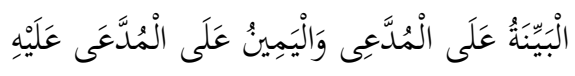

Maksudnya:

Pihak pendakwa hendaklah mendatangkan keterangan/bukti sementara pihak tertuduh hendaklah bersumpah(Al-Bayhaqy 1344H).

Meletakkan makna al-bayyinah kepada semata-mata shahadah sebenarnya menyempitkan usaha menegak keadilan. Ini kerana ia akan mengabaikan sabitan melalui qara'in al-ahwal yang mana kadangkala hujahnya lebih kuat dari shahadah. Sebagai contoh, Rasulullah s.a.w pernah memerintahkan al-Zubair mengambil pengakuan bapa saudara Huyai b. Ahtab (sekalipun dengan cara menyiksa) yang dituduh menyembunyikan harta milik Huyai walaupun ia menafikannya. Ia semata-mata berasaskan qarinah masa yang terlalu singkat. Rasulullah s.a.w telah bersabda: العهد قريب، والمال كثبر yang bermaksud masa terlalu singkat sedangkan harta terlalu banyak (masakan ia boleh habis) (Ibn Farhun 1986; al-Buty 1980; Ibn Qayyim1991). Demikian juga dalam kisah penghakiman nabi Allah Sulaiman terhadap dua orang wanita yang mengaku hak terhadap seorang anak. Menurut Ibn al-Qayyim, Allah s.w.t Maha Bijaksana tidak akan menetapkan suatu kaedah tertentu sebagai keterangan tetapi kemudiannya dinafi dengan petunjuk lain yang lebih kuat, malangnya petunjuk itu tidak dapat dijadikan sebagai dalil keterangan. Ini sudah tentu bercanggah dengan sistem keadilan Islam. Dalam mendokong pendapatnya, Ibn Qayyim telah membawa beberapa contoh dari ayat al-Quran. Antaranya:

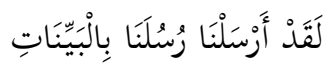

Maksudnya:

Dan sesungguhnya kami, [Allah (s.w.t)] telah mengutuskan rasul-rasul kami dengan membawa bukti-bukti dan mukjizat yang jelas nyata (al-Quran, alHadid 57:35). 


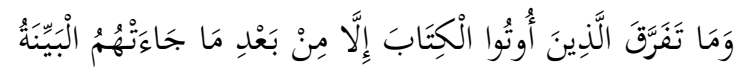

Maksudnya:

Dan orang-orang (Yahudi dan Nasrani) yang diberi kitab (Taurat dan Injil) itu tidak berpecah belah melainkan setelah datang kepada mereka bukti yang jelas nyata (al-Quran, al-Bayyinah 98:4).

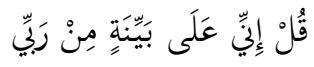

Maksudnya:

Katakanlah: sesungguhnya aku tetap berada diatas (kebenaran yang berdasarkan) bukti-bukti yang nyata (al-Quran) dari Tuhanku (al-Quran, alAn'am 6:57).

Keseluruhan ayat di atas sama sekali tidak memberi makna 'al-bayyinah' sebagai saksi, ini menunjukkan bahawa perkataan tersebut digunakan oleh syarak mengikut pengertiannya yang umum iaitu keterangan, hujah, bukti dan dalil. Apa yang jelas, pendapat ini menerima apa sahaja bentuk keterangan yang dapat membantu menjelaskan, menerangkan, atau membuktikan sesuatu kes yang dibicarakan dalam proses menegakkan kebenaran dan keadilan yang dituntut. Jelasnya, matlamat penghakiman ialah untuk menegakkan keadilan sesama manusia. Oleh kerana itu, mana-mana dalil atau petunjuk yang dapat menzahirkan keadilan dan kebenaran, ia sebenarnya adalah ajaran Islam itu sendiri dan sama sekali tidak bercanggahan dengannya. Jelasnya al-bayyinah mengikut pengertiannya yang sebenar ialah hujah, dalil atau keterangan yang jelas. Pemahaman ini adalah sejajar dengan penggunaannya dalam konteks semasa kanun perundangan.

\section{Al-Qarinah dan Permasalahan Zina}

Sebagaimana yang telah kita maklumi al-qarinah bukanlah merupakan dalil keterangan yang disepakati oleh para fuqaha. Ini kerana segelintir mereka menolak penggunaannya, antaranya ialah Imam al-Khayr al-Ramly (al-Khayr al-Ramly 1974), Imam al-Jassas (alJassas 1993) dan Imam al-Qarafy (al-Qarafy t.th.). Sungguhpun demikian kebanyakan ulama menerimanya sebagai dalil keterangan, malah boleh dikatakan semua mazhab mengamalkan al-qarinah kecuali dalam beberapa masalah tertentu seperti masalah hudud.

Kedudukan al-qarinah sebagai dalil keterangan secara umum seakan tidak perlu didatangkan hujah, ini kerana pemakaiannya dikalangan ulama amat meluas dan ketara. Sekalipun kita menyedari penggunaan al-qarinah tidak disepakati umum, namun dari sudut pengamalan ia menunjukkan sebaliknya. al-Khayr al-Ramly dari mazhab Hanafi dan alQarafi dari mazhab Maliki sekalipun terang-terangan menolak penggunaan al-qarinah tetapi dalam beberapa masalah fikah, mereka telah menggunakannya. Sebagai contohnya Imam al-Qarafi turut beramal dengan al-qafah, nukul dan al-qasamah (sumpah bunuh) sedangkan kesemua hujah-hujah tersebut berasaskan kepada al-qarinah (al-Qarafy t.th.) Begitu juga dengan imam al-Shafii sendiri yang menolak penggunaan al-qarinah telah 
menggunakannya lebih daripada 100 masalah fikah di dalam mazhabnya (Ibn Qayyim 1968). Ringkasnya, boleh dikatakan keseluruhan ulama menerima penggunaan al-qarinah sebagai dalil keterangan namun begitu mereka tetap berselisih pendapat mengenai sejauh manakah ruanglingkup penggunaan dalil tersebut khususnya di dalam permasalahan hudud dan qisas.

Permasalahan hudud melibatkan tujuh jenis kesalahan jenayah, iaitu: kesalahan zina, qazaf (menuduh orang berzina) minum arak, mencuri, murtad, merompak dan memberontak. Sekalipun jenis kesalahan yang terlibat adalah sedikit namun kekerapan jenayah yang berlaku mengikut kategori kesalahan ini adalah terlalu tinggi iaitu mencapai 80\% (al-Qi'ie 1988). Sebagai contohnya dalam satu statistik yang telah dikeluarkan oleh jabatan siasatan jenayah Ibu Pejabat Polis Bukit Aman, Kuala Lumpur, jumlah laporan terhadap kecurian harta benda pada tahun 1986 ialah sebanyak 82314 kes dan yang berjaya diselesaikan hanyalah $10.6 \%$ dari jumlah tersebut. Ini tidak termasuk jenayah kolar putih yang melibatkan kewangan yang sangat besar yang ada kalanya menggugat dan mencemarkan kewibawaan sistem kawalan kewangan negara di kalangan masyarakat di Malaysia dan antarabangsa seperti kes BMF di Hongkong yang melibatkan kerugian melebihi RM2 bilion dan Perwira Habib Bank yang menanggung kerugian sebanyak RM673 juta akibat manipulasi sistem oleh pegawai dan pelanggan bank tersebut (Muhd Reduan 1990). Di samping kekerapan tersebut, ia juga menyentuh kepentingan asas kehidupan manusia. Lantaran itu ia sangat memberi kesan ke atas pembangunan dan keruntuhan sesebuah masyarakat.

Dalam memelihara kepentingan yang besar ini Islam telah mengenakan hukuman yang berat dan mandatori di atas setiap kesalahan yang dilakukan. Sehubungan dengan itu, kaedah pensabitannya juga adalah lebih ketat berbanding dengan hukuman-hukuman yang lain. Oleh kerana itu, kita melihat ada di kalangan ulama yang mengharuskan penggunaan al-qarinah sebagai dalil keterangan dalam masalah takzir, telah menolak penggunaannya di dalam masalah hudud. Secara umumnya pendirian ulama terhadap permasalahan ini terbahagi kepada dua golongan, iaitu: pertamanya, golongan yang menerima al-qarinah sebagai dalil keterangan. Pendapat ini didokong oleh sebahagian besar ulama mazhab Maliki (Malik 1992; al-Kasynawy t.th.), Ibn al-Ghurs al-Hanafï, Ibn Taimiyyah (Ibn Taymiyyah t.th.) dan Ibn Qayyim al-Jawzy al-Hanbali (Ibn Qayyim 1968). Keduanya, golongan yang menolak al-qarinah sebagai dalil keterangan. Pendapat ini didokong oleh kebanyakan ulama dari kalangan mazhab Shafii (Muhammad Sharbini 1957), Hanafi (Muhd Ra'fat 1992), Hanbali (Ibn Qudamah 1969), Zahiri (Ibn Hazm t.th.), Syiah Zaidiyyah (Muhammad Jawwad t.th.) dan Imamiyyah (al-Hully 1985). Nas-nas yang menunjukkan keharusan berhukum dengan al-qarinah dalam kes-kes jenayah dan hudud termasuk zina terlalu banyak. Antaranya ialah athar yang diriwayatkan oleh Ibn Abbas bahawa sayidina Umar b. al-Khattab berkata dalam khutbahnya setelah pulang dari mengerjakan haji:

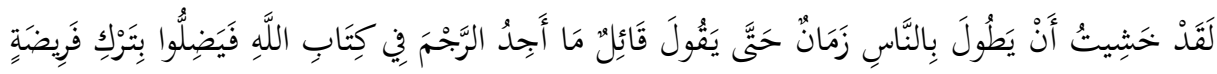

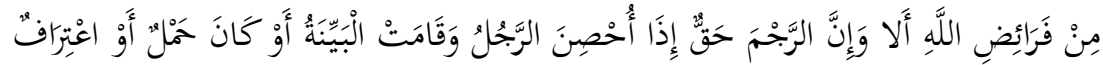

Maksudnya: 
Sesungguhnya saya merasa khuatir lama-kelamaan orang akan berkata, kami tidak bertemu dengan hukum rejam di dalam kitab Allah, dengan demikian mereka telah meninggalkan satu kefardhuan yang telah diturunkan oleh Allah, ingatlah bahawa hukuman rejam itu adalah benar terhadap mereka yang berzina dalam keadaan muhsan apabila cukup keterangan (saksi), mengandung (tanpa suami/tuan) atau pengakuan (Ibn Hajar al-Asqalany 1987; Malik 1992; al-Nawawy 1991).

Kehamilan (dalam keadaan tiada suami atau tuan) adalah al-qarinah yang jelas terhadap perbuatan zina, al-qarinah ini telah diterima oleh saidina Umar sebagai dalil sabitan dalam kes ini. Saidina Umar tidak mengeluarkan kenyataan seperti ini melainkan ia terlebih dahulu mengetahui kepentingan jiwa dan kehormatan seseorang yang tidak boleh dirosakkan dengan hanya semata-mata sangkaan sifat ketelitian sayidina Umar ini amat jelas melalui katanya:

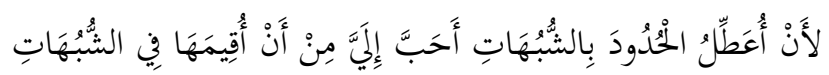

Maksudnya:

Menggugurkan pelaksanaan hukuman hudud kerana wujud syubhah lebih aku sukai dari melaksanakannya dalam keadaan ada syubhah (Shawkany 1983).

Malah pandangan ini bukan hanya didokong oleh beliau sahaja bahkan turut dikongsi bersama oleh Saidina Ali dan Saidina Uthman sepanjang khilafah mereka tanpa bangkangan daripada para sahabat yang lain (Ibn Qudamah 1969). Diriwayatkan oleh Ibn Mas`ud bahawa Saidina Ali berkata:

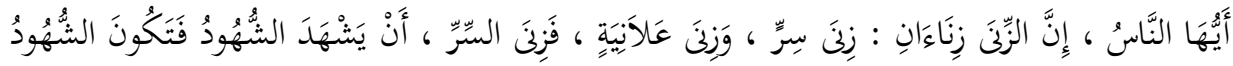

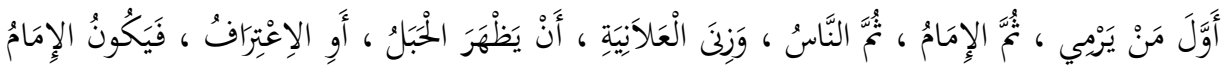

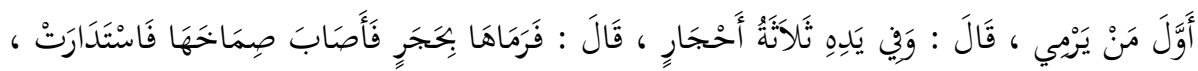

$$
\begin{aligned}
& \text { وَرَمَى النَّاسُ. }
\end{aligned}
$$

Maksudnya:

Wahai manusia, sesungguhnya zina itu ada dua jenis, zina rahsia dan zina terang-terangan, zina rahsia ialah zina yang dibuktikan melalui kesaksian, maka saksi adalah orang yang pertama melontar, kemudian imam dan kemudian orang ramai. Zina terang-terangan pula ialah zina yang dibuktikan melalui mengandung atau pengakuan bersalah, maka imam adalah orang yang pertama melontar. Ibn Mas'ud berkata "di tangannya (Saidina Ali) ada tiga ketul batu, lalu baginda melontar dan mengenai mukanya, perempuan 
itu berpaling, kemudian barulah orang ramai mula melontar (Ibn Qudamah 1969).

Athar ini menunjukkan dengan jelas bahawa Saidina Ali menerima al-qarinah mengandung sebagai dalil sabitan terhadap zina. Dalam hal sebegini, imam adalah orang yang pertama melakukan lontaran. Dalam sebuah athar dari Saidina Uthman yang diriwayatkan oleh Imam Malik:

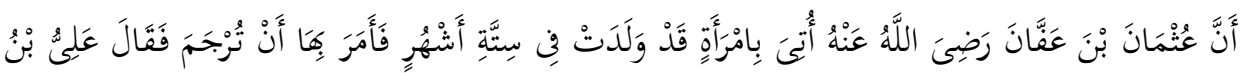

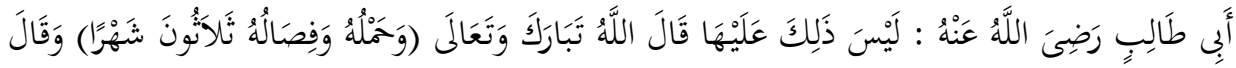

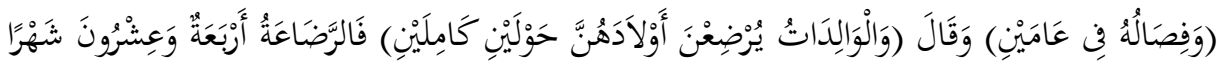

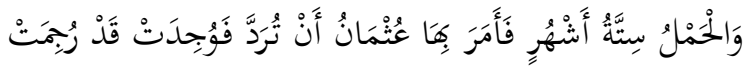

Maksudnya:

Telah datang seorang perempuan yang telah melahirkan anak dalam masa enam bulan (tempoh perkahwinan mereka) kepada Saidina Uthman b. 'Affan, lalu baginda memerintahkan agar ia direjam. Saidina Ali berkata kepadanya; "Bukan itu hukuman keatasnya, sesungguhnya Allah telah berfirman (yang bermaksud): Masa mengandung dan bercerai susunya ialah tiga puluh bulan. Dan Allah berfirman lagi: Ibu ibu yang ingin menyusukan anaknya adalah dua tahun bagi mereka yang ingin menggenapkan penyusuan. Lantaran itu (kata Saidina Ali): Sekurang-kurang mengandung ialah enam bulan, kerana itu perempuan itu tidak boleh direjam". Lalu Saidina Uthman mengutus utusan untuk menjejaki perempuan itu dan didapatinya ia telah direjam (Malik 1992).

Melalui hadis ini, Saidina Uthman menjatuhkan hukuman rejam ke atas wanita tersebut berasaskan kepada al-qarinah kehamilan/melahirkan anak. Sekalipun hukuman tersebut dibantah oleh Saidina Ali namun bantahan itu bukan kerana tidak memperakukan al-qarinah hamil/melahirkan anak, sebaliknya kerana ia melahirkan anak dalam tempoh enam bulan.

\section{Dalil Ijmak}

Dalam pada itu, kenyataan 'Umar di dalam khutbah Jumaat mengenai sabitan al-qarinah zina melalui kehamilan tidak dibangkang oleh para sahabat. Ini menunjukkan para sahabat bersetuju dan sependapat terhadap perkara tersebut. Perkataan seorang sahabat yang zahirnya adalah merupakan seorang ulama/sahabat besar, mengungkapkan suatu pernyataan sehingga ia diketahui umum tetapi tiada kedengaran suara bangkangan. Apakah ia dikira ijmak atau tidak?. Dalam menghurai masalah ini ulama berselisih pendapat kepada beberapa mazhab, iaitu: 
- Ijmak. Pendapat ini didokong oleh imam Shirazi, majoriti penganut mazhab Hanafi dan Imam Ahmad b. Hanbal.

- Ia adalah hujah tetapi bukan ijmak. Pendapat ini di dokong oleh imam Ibn alHajib, imam al-Amidi dan imam al-Rafi'i.

- Sekiranya perkataan itu zahir dari seseorang yang bersifat hakim ia bukan ijmak. Pendapat ini di dokong oleh Abu Ali b. Abu Hurairah.

- Ia bukan hujah. Pendapat ini didokong oleh Abu Bakar al-Ash`ari, mazhab Shafii, mazhab Daud dan Imam al-Razi.

Menurut Imam Shirazi pendapat yang kuat ialah pendapat yang pertama kerana diamnya para sahabat adalah tanda mereka reda terhadap keputusan tersebut. Pada kebiasaan di kalangan sahabat Rasulullah s.a.w apabila datang sesuatu masalah yang baru mereka akan berijtihad dan mencari hukumnya serta berpegang dan melahirkan pandangan mereka sendiri. Oleh itu apabila tiada bangkangan dalam suasana dan keadaan yang terbuka luas untuk berbuat demikian hakikatnya adalah menunjukkan bahawa mereka reda terhadap pendapat tersebut (al-Shirazi 1983).

\section{Dalil Logik Akal}

Telah sabit di kalangan ulama bahawa wajib dijalankan hukuman hudud terhadap penzina apabila cukup empat orang saksi. Jika demikian pembuktian melalui al-qarinah kehamilan adalah lebih utama untuk disabitkan kerana sabitannya terhadap tuduhan adalah lebih kuat dan jelas. Ini kerana seorang saksi boleh jadi tersalah pandang, tersilap atau boleh jadi juga mereka berbohong. Berbeza dengan kehamilan yang tidak berlaku melainkan dengan cara percampuran air mani lelaki dan perempuan yang lazimnya berlaku melalui persetubuhan. Walaupun kaedah perubatan telah membuktikan kewujudan permanian beradas atau bayi tabung uji, namun kemungkinan berlakunya kejadian itu akan disokong oleh faktafakta lain yang dapat menafikan ianya hasil dari persetubuhan tabii. Di samping itu saksi adalah bukti luar manakala kehamilan adalah bukti yang wujud pada diri tertuduh. Ringkasnya, darjah keraguan yang wujud pada seseorang saksi adalah lebih tinggi berbanding dengan andaian-andaian lain dari kehamilan tanpa suami melainkan zina.

Dalil-dalil tersebut serta dalil-dalil lain secara konsepnya menjadi bukti keharusan al-qarinah sebagai dalil sabitan. Walaupun begitu keadaan dan bentuk al-qarinah akan berubah mengikut perubahan masa, tempat dan keadaan. Sebagai contoh, dalam kes ghamidiyyah, nabi s.a.w telah meminta para sahabat mencium bau mulut wanita itu untuk memastikan ia tidak mabuk (akibat minum arak) ketika membuat pengakuan. Dalam konteks ini kemungkinan al-qarīnah bau tidak lagi kuat berbanding dengan kecanggihan alat moden yang dapat menentukan kandungan alkohol dalam badan. Kemungkinan juga kisah kehakiman Sayidina Ali (r.a) dalam kes pembunuhan seorang pemuda yang dibuktikan dengan al-qarinah pisau yang berlumuran darah serta keadaan tertuduh dalam ketakutan tidak lagi kuat berbanding dengan cap jari dan ujian DNA pada hari ini. Jelasnya apa yang perlu diambil iktibar dari nas-nas tersebut adalah konsepnya dan bukan bentuknya secara terperinci. 


\section{Sains dan Relevansinya Sebagai Bahan Bukti}

Penggunaan kaedah saintifik untuk mencari bukti telah digunakan semenjak zaman Rasulullah s.a.w lagi. Rasulullah s.a.w pernah menghidu bau mulut seseorang untuk mengetahui sama ada ia berada di bawah pengaruh arak atau tidak. Saidina Ali pula pernah menggunakan air panas untuk menyiasat kesan melekit pada kain seorang perempuan untuk mengetahui sama ada ia kesan mani atau bukan. Walaupun kedua-dua contoh ini contoh mudah, ia sebenarnya melambangkan tahap sains ketika itu. Pencapaian sains dan teknologi pada masa ini amat jauh berbeza berbanding di zaman awal Islam. Beberapa penemuan sains pada hari ini telah berjaya meletakkan sesuatu keterangan pada tahap yakin atau tanpa keraguan yang munasabah seperti penemuan cap jari, ujian DNA, ujian darah, forensic voiceprints, imageprints, faceprints dan sebagainya. Keadaan ini sebenarnya telah menambah dan memperkayakan kaedah pembuktian dalam Undang-Undang Keterangan Islam. Ia juga mengukuhkan kekuatan bukti seiring dengan kecanggihan jenayah. Terdapat banyak ayat dalam al-Quran yang menjelaskan peranan sains dalam kehidupan manusia. Sebagai contoh firman Allah:

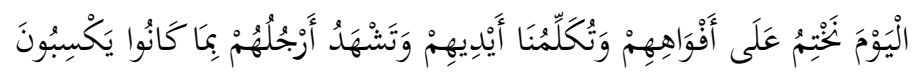

Maksudnya:

Pada hari ini Kami kunci mulut-mulut mereka dan tangan-tangan mereka akan bercakap kepada kami serta kaki-kaki mereka menjadi saksi terhadap apa yang mereka kerjakan (al-Quran, Yasin 36:65).

Menurut Sheikh Tantawy jauhari menerusi kitabnya al-Jawahir fi Tafsir al-Quran alKarim menjelaskan bahawa ayat di atas disamping menceritakan mengenai keadaan manusia di hari kiamat kelak ia juga menyebut tentang bagaimana tangan-tangan manusia boleh berbicara di dunia ini, iaitu melalui kesan cap jari (Tantawy Jawhary 1351H). Malah melalui kajian moden hari ini cap jari bukan sekadar digunakan sebagai pengenalan diri malah boleh mengetahui potensi diri seseorang. Firman Allah juga:

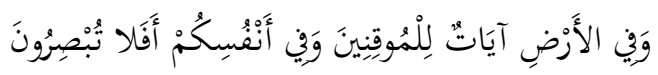

Maksudnya:

Dan pada bumi ini ada tanda-tanda kebesaran Allah bagi mereka yang yakin. Dan juga pada diri kamu sendiri, kenapa kamu tidak mahu melihat (alQuran, al-Zariyat 51:21).

Penemuan sains pada diri manusia adalah merupakan sunnatullah yang Allah ciptakan pada diri manusia itu sendiri. Ia adalah sebahagian dari bukti bahawa al-Quran itu adalah kalam Allah yang benar. 


\section{Hubungan antara al-Qarinah dan Maslahat}

Memelihara kemaslahatan adalah merupakan maqasid shariah. Oleh itu Islam sangat mengambil berat kedudukan ini. Kemaslahatan manusia pada asasnya berpijak kepada lima struktur penting, iaitu keselamatan dari sudut agama, jiwa, akal fikiran, keturunan dan harta. Jika diamati didapati bahawa kesalahan-kesalahan hudud melibatkan kelima-lima kemaslahatan tersebut. Oleh itu tidak dapat dinafikan bahawa perlaksanaan hukuman hudud adalah penting untuk kemaslahatan manusia. ${ }^{4}$ Pada pandangan penulis ada dua sebab utama mengapa sabitan melalui al-qarinah sangat perlu dinilai semula. Pertamanya, perkembangan teknologi moden memungkinkan sesuatu perkara itu dapat diketahui dengan tepat dan yakin. Malah teknologi ini telah dimanfaatkan oleh seluruh masyarakat dunia dalam penyiasatan kepolisian mereka. Adalah satu kerugian bagi umat Islam jika mereka mengabaikan aspek ini setelah jelas ia merupakan salah satu cara yang dapat menzahirkan keadilan dan telah teruji. Keduanya, Kebersihan dan kekentalan iman semakin pudar. Kenyataan ini tidak dapat dinafikan malah keadaan sekeliling telah membuktikannya. Sementara jenayah pula dilakukan dalam bentuk yang lebih sofistikated dan amat sukar dikesan. Untuk mencari saksi (syahadah) atau pengakuan bersalah (ikrar) dalam mana-mana kes jenayah seakan tidak wujud lagi pada masa ini. Dengan meninggalkan al-qarinah akan mengetepikan banyak keadilan. Dan dalam masa yang sama ia membawa tohmahan terhadap ketidaksesuaian sistem keadilan dan kehakiman Islam itu sendiri. Dalam persoalan ini Sheikh `Abd al- Rahman Taj berkata:

Adalah keterlaluan di dalam memutuskan sesuatu polisi dan bersifat jumud serta tidak akan dapat membela keadilan dan keamanan apabila seseorang hakim itu membataskan kaedah pembuktian hanya kepada shahādah dan iqrar atau nukul 'an al-yamin dengan tidak mengambil kira al-qarinah dan shawahid al-ahwal (bukti sekeliling), kerana ada kalanya kedua-dua dalil tersebut lebih kuat dan hampir kepada kebenaran serta lebih jelas dalam menegakkan keadilan terutamanya pada waktu banyak berlaku pendustaan, penyelewengan dan saksi palsu (Abdul Rahman Taj 1988).

\section{Hubungan antara al-Qarinah dengan Sad al-Zara ì}

Sad al-zara ${ }^{\prime c}$ adalah salah satu kedah usul fikah untuk mengistinbatkan sesuatu hukum syarak (Abdul Kari Zaidan 1974). Pada bahasanya sad bermaksud tutup dan al-zari ah bermaksud jalan untuk mencapai kepada sesuatu, manakala pada istilah ulama usul, ia adalah sesuatu perkara yang hukumnya harus tetapi digunakan sebagai jalan untuk

${ }^{4}$ Ia digolongkan dalam maślaĥhah d'arūriyyah. Sheikh cAbd al- Rahmān Tāj , al-Siyāsah alsharciyyah wa al-fiqh al-islāmī, Majallat al-azhar edi. Ramadan, Cairo, 1415H, hlm. 56; Dewasa ini keperluan kepada hukuman hudud amat ketara, kepincangan masyarakat telah sampai ke tahap yang membimbangkan, gejala murtad menjadi isu yang hangat diperbincangkan (tidak ada undangundang dapat menghalangnya), pelacuran, seks rambang, bohsia dan bohjan menjadi istilah yang meniti dibibir remaja, (27\% remaja di Malaysia telah melakukan hubungan seks tanpa nikah). Penggelapan wang, kecurian, rompakan, (adakalanya melibatkan kehilangan nyawa) ketagihan dadah, arak dan sebagainya. Malah wujud satu fenomena baru dimana maksiat-maksiat yang ditegah ini telah menjadi satu kebanggaan pula kepada sesetengah pihak dan seterusnya menghina Islam. 
mencapai kepada suatu yang haram atau mafsadah. (Abdul 'Al 1993). Jelasnya penggunaan Sad al-zara $i$ bermaksud menegah sesuatu perkara yang hukum asalnya adalah harus tetapi sering digunakan untuk mencapai tujuan yang haram. Niat jahat atau tujuan haram ini boleh difahami melalui qarinah. Contoh sad al-zara $i$ ialah perbuatan nikah cina buta atau tipu helah yang tidak mengikut syarak seperti berjual beli untuk mengelakkan riba. Ia boleh berlaku dengan cara menjualkan sesuatu benda dengan nilai RM100.00 secara hutang kemudian membelinya semula dengan nilai RM 90.00 tunai. Pada asasnya nikah dan jual beli adalah halal tetapi kaedah ini sering digunakan untuk mencapai tujuan yang diharamkan. Pendapat ini didokong oleh mazhab Maliki dan Hambali manakala mazhab alShafii dan al-Zahiri tidak menerimanya, sebaliknya mereka mensyaratkan kepada suatu dalil lain yang dapat menunjukkan tujuan asalnya adalah riba. Selama mana dalil ini tidak dibuktikan maka hukumnya tetap harus. Hujah mereka ialah suatu perkara itu selamamana ianya harus ia tidak boleh ditegah dengan semata-mata andaian bahawa ia bertujuan jahat, kerana andaian ini adakalanya benar dan adakalanya salah. Oleh itu ia tergolong dalam perkara zan. Ia tidak dapat melawan yakin (Abdul Karim 1974). Pada pandangan penulis, pendapat mazhab Maliki dan Hambali adalah lebih kuat dan lebih utama untuk diikuti. Ini kerana sekalipun sad al-zara ï merupakan andaian tetapi ia adalah andaian yang kuat (zan al-ghalib). Zan al-ghalib diterima sebagai dalil dalam syariat Islam.

Islam menegah kemungkaran dan serentak dengan itu ia menutup pintu-pintu yang boleh membawa kepada kemungkaran tersebut. Islam juga tidak alpa dalam melihat matlamat dan kecenderongan sesuatu perkara, jika jelas ia condong kepada fasad Islam menutup jalannya sedari awal. Oleh sebab itulah diharamkan meminang pinangan orang lain kerana ia boleh membawa pertelingkahan sesama umat Islam. Tambahan pula dewasa ini dalam suasana masyarakat yang hampir rosak dan banyak berlaku fasad, hukum syariat tidak lagi diindahkan. Dalam situasi ini, sad al-zara i serasa amat perlu bukan sahaja untuk menjamin keadilan tetapi lebih dari itu untuk membela kesucian Islam dari dipermainmainkan. Di manakah kemunasabahannya, seorang pelacur yang telah dikenali umum ditangkap ketika berada di tempat dan masa yang amat meragukan boleh melepaskan diri dengan semat-mata mengatakan "di mana saksi kamu"? Adakah kamu boleh mendatangkan empat orang saksi yang adil melihat saya melacur?. Sememangnya keadaan begini amat sukar untuk dibuktikan melalui shahadah, apatah lagi perbuatan zina (bukan pelacuran) yang dilakukan dalam keadaan tersembunyi. Hakikatnya semua mengetahui, kadar pembuangan anak, kehamilan di luar nikah, fenomena bohjan semakin menjadi-jadi. Apakah ungkapan "dimana saksi kamu" dapat menyelesaikan masalah ini? Meninggalkan alqarinah memberi ruang yang luas kepada pesalah untuk melepaskan diri, dalam masa yang sama keadilan gagal ditegakkan. Lebih dari itu, hukum Islam mudah dipermain-mainkan.

\section{Hubungan antara al-Qarinah dan Kaedah Fikah}

Kaedah fikah adalah himpunan hukum-hukum fikah yang berada dibawah satu tajuk tertentu dipadatkan menjadi satu prinsip umum (Mustafa Zarqa' 1989). Ia tidak boleh mensabitkan sesuatu hukum sebagaimana usul fikah sebaliknya merupakan rumusan terhadap hukum-hukum fikah yang sedia ada. Dalam menyentuh persoalan al-qarinah ini, satu kaedah fikah ada menyatakan: الثابت بالبرهان كالثابت بالعيان yang bermaksud pensabitan melalui dalil dan bukti samalah kedudukannya dengan pensabitan melalui penglihatan. AlBurhān bermaksud keterangan dari seorang yang adil (Mustafa 1989; Mahmud Saedon 
1990). Kaedah ini bermaksud bukti keterangan seorang yang adil mencapai kekuatan sama seperti keterangan yang diperolehi melalui penglihatan pancaindera atau saksi. Yang dimaksudkan dengan keterangan ialah dalil yang berupa hujah atau bukti-bukti lain termasuk al-qarinah. Satu perkara yang membezakan antara keterangan yang berasaskan kepada penglihatan pancaindera dengan keterangan yang berupa dalil-dalil ialah sabitan melalui pancaindera atau saksi tidak akan menerima sebarang dakwaan sebaliknya. Berbeza dengan keterangan yang berasaskan kepada bukti-bukti. Jika ada dakwaan menyanggahinya maka dakwaan itu hendaklah didengar terlebih dahulu. Dalam menghuraikan perkara yang sama Mahmud Saedon (1990) berkata:

Keterangan berdasarkan penglihatan adalah diterima dan merupakan keterangan yang kuat. Kesaksian adalah daripada jenis keterangan yang sabit melalui penglihatan orang yang memberi kesaksian tersebut. Walaupun demikian keterangan yang bukan berdasarkan penglihatan tetapi berdasarkan dalil, hujah atau bukti-bukti lain juga adalah diterima. Kaedah ini menegaskan pensabitan berdasarkan hujah adalah diterima sama seperti pensabitan melalui penglihatan.

\section{Al-Qarinah dan Syubhah}

Antara alasan popular yang menghalang pelaksanaan qarinah dalam sabitan jenayah ialah pembuktian dalam kes-kes jenayah mesti dibuktikan sehingga mencapai tahap yakin atau tanpa sebarang keraguan. Hukum ini merujuk kepada sabda Rasulullah s.a.w yang bermaksud:

Hindarilah dari melaksanakan hukuman hudud sekiranya ada keraguan, elakkan dari menjatuhkan hukuman bunuh ke atas orang Islam sedaya upaya yang kamu boleh (Syawkani 1983).

Di sini ada dua persoalan: pertama, jenis dalil sabitan yang mencapai tahap yakin dan kedua, maksud keraguan. Berhubung persoalan pertama, mahkamah berpendapat bahawa syahadah dan iqrar adalah merupakan dua dalil sabitan yang terkuat dan dikategorikan sebagai dalil sabitan yang mencapai tahap yakin. Manakala qarinah, sejauhmanapun kekuatannya ia tidak melebihi zan al-ghalib (berat sangka). Pemahaman ini secara langsung telah menafikan peranan qarinah dalam mensabitkan jenayah hudud. Pada pandangan penulis, status yakin yang diberikan kepada shahadah dan iqrar bukanlah yakin dari sudut hakikatnya. Ini kerana sejauhmanapun kekuatan dalil tersebut ia juga terdedah kepada kesilapan seperti kemungkinan saksi berbohong atau pengakuan palsu yang berkepentingan. Oleh yang demikian yang dimaksudkan sebagai yakin mengikut pengertian mahkamah ialah ia mengikat hakim dalam melaksanakan sesuatu hukuman. Berbeza dengan al-qarinah, setinggi manapun kekuatannya ia tidak mengikat hakim. Justeru, dalam konteks ini kekuatan atau autoriti sesuatu dalil sebenarnya bukan bergantung kepada jenis dalil tersebut tetapi bergantung kepada sejauhmana dalil itu dapat memperlihatkan keadilan dan kebenaran. 
Berbalik kepada persoalan kedua, apakah sebenarnya maksud 'syubhah'? Adakah ia membawa maksud tanpa sebarang keraguan atau tanpa keraguan yang munasabah? Dalam persoalan ini penulis merasakan pengertian 'syubhah' sekadar membawa maksud tanpa keraguan yang munasabah. Pendapat penulis pertamanya berpandukan kepada fakta keterangan diatas dimana tidak ada satupun kaeadah sabitan yang mencapai tahap yakin tanpa sebarang keraguan. Keduanya merujuk kepada pandangan ulama mengenai pengertian 'syubhah' itu sendiri. Imam al-Sayuti rahimahullah dalam mensyarahkan kaedah (hukuman hudud gugur apabila wujud keraguan) turut sama mensyarahkan syarat-syarat syubhah tersebut. Ia berkata syarat sesuatu syubhah itu diterima hendaklah ia merupakan syubhah yang kuat, jika tidak ia tidak akan memberi apaapa kesan dalam menggugurkan hudud (al-Sayuti 1983). Jelasnya apa yang dikatakan oleh Imam al-Sayuti, bukan semua syubhah boleh menggugurkan hudud sebaliknya hanya syubhah yang kuat atau dalam perkataan lain yang 'munasabah' sahaja boleh diterima. Imam al-Shawkani dalam menghuraikan pengertian hadis ini juga berpendapat sedemikian. Maksud syubhah menurutnya bukanlah semata-mata andaian (mutlaq al-syubhah) tetapi mestilah andaian yang munasabah (syubhah al-muhtamalah) (Syawkani 1983). Kaedah fikah juga ada menyatakan لاعبرة للتوهم (suatu yang bersifat waham tidak diambil teladan/panduan). Kaedah ini membawa maksud, sesuatu hukum tidak boleh diistinbat hanya berasaskan kepada perkara-perkara yang waham, iaitu semata-mata andaian, sebaliknya mestilah berdasarkan kepada dalil yang kuat atau zahir keadaan termasuk andaian yang munasabah (Mustafa Ahmad 1989). Seorang wanita yang mengandung dalam keadaan tiada suami atau tuan adalah al-qarinah al-zahirah (fakta yang jelas) bahawa ia telah berzina, apa-apa kemungkinan seperti ia memasukkan sendiri air mani lelaki kedalam farajnya dengan tangan adalah sesuatu yang mungkin boleh berlaku, tetapi ia hanyalah semata-mata waham sehinggalah dibuktikan. Syariat tidak mengambil hukum dari perkara yang waham jika berhadapan dengan dalil yang pasti atau zahir.

Seperkara lagi, pertuduhan bukanlah pengakhiran sesuatu perbicaraan, sebaliknya ia adalah titik mula untuk mengenal pasti kebenaran. Setelah segala keterangan dan buktibukti serta hujah dakwaan dan penolakan dikemukakan barulah satu keputusan yang diyakini diperolehi. Hasil keputusan inilah fokus sebenar maksud hadis Rasulullah s.a.w (al-Shawkani 1983). (Elakkan perlaksanaan hukuman hudud atas perkara-perkara yang ada keraguan). Al-qarinah adalah salah satu kaedah sabitan yang telah mendapat tempat sejak mula sistem keadilan diperkenalkan. Walaupun begitu para ulama terdahulu menampakkan keraguan untuk memperluaskan penggunaannya dalam kes-kes jenayah. Prinsip asasnya ialah al-qarinah dianggap mengundang keraguan atau syubhah. Kaedah tradisi yang diguna pakai ialah dalil sabitan yang tidak menimbulkan 'syubhah' hanyalah syahadah dan iqrar. Justeru itu dalil sabitan al-qarinah ditolak. Hakikatnya kemajuan sains dan teknologi serta teknik penyiasatan moden yang sofistikated mampu meletakkan keterangan al-qarinah ke tahap yakin atau tanpa keraguan yang munasabah. Kemajuan sains dan teknologi ini sebenarnya telah mengubah realiti masa lampau. Sebagai contoh sebuah fatwa dari Imam al-Subky: "jika 'hisab' menafikan kemungkinan melihat anak bulan (Ramadan/Syawal) maka qadhi hendaklah menolak keterangan saksi yang melihat anak bulan. Kerana hisab adalah qat'iy manakala saksi hanyalah khabar zanny". Di samping itu objektif sesuatu undang-undang ialah untuk menegakkan keadilan. Jika keadilan dapat dicapai melalui dalil qarinah maka mustahil ia tidak diambil kira oleh Allah s.w.t semata-mata kerana ianya bukan syahadah atau iqrar. 
Justeru, saya cenderung untuk membuka pemikiran pembaca terhadap pentingnya alqarinah menjadi asas kepada sabitan semua kes termasuk kes-kes jenayah.

\section{References}

Abd al-`Al Ahmad 'Utwawah. 1993. al-Madkhal ila al-Siyasah al-Shar`iyyah. Riyadh: Universiti Imam Muhammad bin Saud.

Abd al-Karim Zaidan. 1974. al-Wajiz fi Usul al-Fiqh. Baghdad: Matba'ah Salman al-A'jamy.

Abd al-Rahman Taj. 1988. Al-Siyasah al-Shar’iyyah wa al-Fiqh al-Islamy. Cairo: Majallat alAzhar.

Abu Bakar bin Hasan al-Kasynawi. t.th. Asl al-Madarik Sharh Irshad al-Salik fi fiqh Imam alA'immah Malik. Jld. 3. Cairo: Maaba’at Isa al-Babi al-Halabi Wa Awladuh.

'Adnan Hasan 'Azayizah. 1990. Hujjiyat al-Qara'in fi al-Syari'ah al-Islamiyyah (al-Basamah, al-Qiyafah, Dalalat al-Athar, Tahlil al-Dam). Amman: Dar 'Ammar.

Al-Baihaqi, Abu Bakar Ahmad bin Husayn. 1344H. al-Sunan al-Kubra. Haidar Aabad: Majlis Da'irat al-Ma'arif al-Nizamiyyah.

Al-Baihaqi, Abu Bakar Ahmad bin Husayn. 1993. al-Sunan al-Saghir. Beirut: Dar al-Fikr.

Al-Buti, Muhd Sa`id Ramadan. 1980. Fiqh al-Sirah, Dirasat Manhajiyyah Ilmiyyah li al-Sirat al-Mustafa 'Alaih al-Salam. t.tp: Dar al-Fikr.

Enakmen Keterangan Mahkamah Syariah 1994 Negeri Perak.

Al-Hully Abu al-Qasim, Abu al-Qasim Najm al-Din Ja`far b. Hasan. 1985. al-Mukhtasar alNafi . Beirut: Dar al-Ad'wa'.

Ibn al-Qayyim al-Jawzy. Syamsuddin Abu Abdullah Muhammad. 1996. Bada'i al-Fawaid. Makkah: Maktabah Nazzar Mustafa al-Baz.

Ibn al-Qayyim al-Jawzy, Syamsuddin Abu Abdullah Muhammad. 1968. I'lam al-Muwaqqi in 'an Rab al-'Alamin. Cairo: Maktabat al-Kulliyyat al-Azhariyyah.

Ibn al-Qayyim al-Jawzi, Syamsuddin Abu Abdullah Muhammad. 1991. Turuq al-Hukmiyyah fi al-Siyasah al-Syar'iyyah. Beirut: Dar al-Fikr al-Lubnany.

Ibn Farhun, Burhanuddin Ibrahim bin Ali. 1986. Tabsirat al-Hukka fi Usul al-'Aqdiyyah Wa Manahij al-Ahkam. Cairo: Matba'ah al-Kulliyyah al-Azhariyyah.

Ibn Hajar al-Asqalani. 1987. Fath al-Bari. Cairo : Dar al-Maktabah al-Salafiyyah.

Ibn Hazm, Abu Ali Muhammad bin Ahmad bin Said. t.th. al-Muhalla. Beirut: Maktabah alTijary li al-Tiba'ah wa al-Nasyr wa al-Tawzi'.

Ibn Qudamahm Abu Muhammad Abdullah b. Ahmad. 1969. al-Mughni. Cairo: Maktabah alQahirah.

Al-Jassas, Abu Bakr Ahmad al-Razzy.1993. Ahkam al-Quran. Beirut: Dar al-Fikr.

Al-Khair al-Ramly.1974. al-Fatawa al-Khayriyyah Li Naf'iy al-Barriyyah. Beirut: Dar alMa'rifah.

Mahmud Saedon Awang Osman. 1990. Undang-undang Keterangan Islam. Kuala Lumpur: Dewan Bahasa dan Pustaka.

Malik bin Anas. 1992. al-Muwatta'. Istanbul: Dar al-Sahnun.

Muhammad al-Sharbini al-Khatib. 1957. Mughni al-Muhtaj ila Ma'rifat Ma'ani al-Alfaz alMinhāj. Cairo: Matba`at Mustafa al-Babi al-Halabi wa Awladuh.

Muhammad Jawwad Maghniah. t.th. Fiqh al-Imam Ja'far al-Sadiq. Qom: Intisyarat Quds Muhammadi. 
Muhd Ra'fat Othman. 1992. al-Qadha' fi al-Fiqhi al-Islami. Tanta: Maktabah al-Azhar alHadithah.

Muhd Reduan Aslie.1990. Jenayah di Malaysia, Aliran, Punca Penyelesaian. Kuala Lumpur: AMK. Interaksi.

Mustafa Ahmad Zarqa'. 1989. Sharh al-Qawa ìd al-Fiqhiyyah. Damascus: Dar al-Qalam.

Al-Nawawy, Abu al-Husain Muslim b. Hajjaj. 1991. Sahih Muslim. Cairo: Muassasah Qurtubah.

Al-Qarafy, Syihabuddin Abu al-Abbas Ahmad. t.th. al-Furuq. Beirut: Matba'ah al-'Alam alKutub.

Al-Qi'ie, Muhammad Abdul Mun'im. 1988. Nazrat al-Quran ila al-Jarimah Wa al-'Iqab. Cairo: Dar Al-Manar.

Al-Qurtuby, Abu `Abdullah Muhammad ibn Ahmad Ibn Abu Bakr ibn Farh al-Ansary. 1964. al-Jami' li Ahkam al-Quran- Tafsir al-Qurtubiyy. Cairo: Dar al-Kutub al-Misriyyah.

Al-Sayuti, Jalal al-Din `Abd al-Rahman. 1983. al-Ashbah wa al-Nazair. Beirut: Dar al-Kutub al-Ilmiyyah.

Al-Shawkany, Muhammad bin Ali b Muhammad.1983. Nayl al-Awtar. Beirut: Dar al-Fikr.

Al-Shawkany, Muhammad bin Ali b Muhammad. t.th. Fath al-Qadir al-Jami' bayn Fann alRiwayah wa al-Dirayah Min 'Ilm al-Tafsir. t.tp.: t.pt.

Al-Shirazi, Abu Ishak Ibrahim bin `Ali b. Yusuf al-Fairouz Abadi. 1983. al-Tabsirah fi Usul alFiqh. Damascus: Dar al-Fikr.

Al-Tantawy, Jawhary. 1351. al-Jawahir fi Tafsir al-Quran. Cairo: Matba'ah Mustafa al-Babi alHalabi. 